\title{
Back to the drawing board
}

\section{Washington}

A rwo-year-old experiment in the investigation of scientific misconduct has blown up in the face of the US National Institutes of Health (NIH). The special office that NIH set up to investigate allegations of scientific misconduct has come under courtroom and congressional attack, and late last year a district judge in Wisconsin ruled that the office's procedures were illegal.

Now, as a host of similar lawsuits raise the prospect of NIH's misconduct rules being declared illegal in the rest of the country, the agency has decided to start the process again from the beginning. Officials say that within weeks NIH will publish in the Federal Register proposed new rules and procedures for the Office of Scientific Integrity (OSI), the department in question.

The move comes some three months after a crucial decision in the case of James Abbs, a researcher at the University of Wisconsin, who had been under investigation for alleged data fabrication (see Nature 349, 95; 10 January 1991). The judge in that case ruled that NIH's investigation was illegal because OSI's internal procedures had been created in camera. The law demands that such procedures be published for public comment before they become law. At least two other lawsuits citing the Abbs decision have been filed since then (see Nature 349, 357; 31 January 1991).

NIH intend to concede the issue and comply with the Administrative Procedures Act, says William Raub, acting director of NIH. The act requires that any proposed rules that could injure people outside government must be published with a comment period during which members of the public can suggest changes. Because OSI has taken the authority to go beyond simple investigations to the point of imposing sanctions (such as stopping a grant), it is subject to the act.

During the forthcoming rule-making process, which typically lasts for one to two years, OSI will have no legal procedures under which to operate. Nevertheless, NIH intend to continue investigating misconduct cases, but on a 'case-by-case basis' as they did before OSI was established in 1989.

"Before OSI was started, we thought we could handle investigations without written procedures", Raub says. "We thought the cases would be so few and so different that we wouldn't have to write things down. We were wrong."

OSI was created to bring order to the investigation process. But critics soon noted that the OSI, like NIH before it, tended to make up procedures as it went. (In the case of AIDS researcher Robert Gallo, for example, OSI asked the National Academy of Sciences to help it to set up a special advisory panel.) Faced with bitter complaints of arbitrary and capricious rule-making, OSI decided to formalize and publish its current rules (see Nature 346, 9; 1990).

That, however, turned out to be a fatal mistake. A federal office with no rules may draw criticism, but an office that creates rules that conflict with the Administrative Procedures Act risks courtroom challenge, as NIH discovered.

Abandoning its existing procedures may lift the legal cloud over OSI for the moment, but it is unlikely to end its problems. If the office continues to impose sanctions, further lawsuits can be expected. Worse still, there is the possibility that researchers whose cases have already been closed may sue on the grounds that they were investigated under illegal rules. But Raub says that he can see no better way out. "Doing nothing is not an option", he says.

Robert Charrow, a Washington attorney, suggests a solution. If NIH would give up sanctions, he says, their legal problems could be over. "They ought to announce that all they will do is investigate, and then simply use the accepted hearing processes that are already in the books." NIH may eventually have to adopt that course. But until it is forced to abandon sanctions, the agency is eager to retain the right to halt research funding when the evidence indicates misconduct, if only for the sake of appearances.

Although the final decision on when or whether to publish new OSI procedures is now in the hands of the Justice Department, where lawyers are still considering their options, NIH officials are already writing the proposed rules. Raub says that the first draft will essentially codify the existing procedures. "We'll use that as a starting point", he says.

Concern in the scientific community is likely to centre on the issue of 'due process' - the protections and civil liberties guaranteed in US courts. Although NIH officials point out that OSI is not a court, several lawsuits have argued that an OSI investigation is as arduous as a criminal investigation, and can take far longer (in some cases more than two years). In particular, researchers have complained that the OSI rules do not give them the right to confront their accuser faceto-face and to see the evidence against them. But NIH, in an effort to protect whistleblowers, intend to fight that point.

Once NIH publish the new OSI procedures, there will be a comment period (typically 90 days) during which the agency will accept any public input. OSI will then rewrite the rules in line with public consensus and legal concerns. Finally, a finished version of the rules will be published in the Federal Register and become law, ready for the next batch of misconduct cases. As for cases now under way or already closed, the courts appear to be the next battleground.

Christopher Anderson

\section{Black eye for NIH}

\section{Washington}

OFFICIALS at the National Institutes of Health (NIH) bungled a case of apparent conflict of interest, even after Congress pointed it out to them almost a year ago, a new investigation has revealed. The case itself is relatively pedestrian - Prem Sarin, deputy chief of AIDS pioneer Robert Gallo's NIH laboratory, is alleged to have illegally consulted with industry and set up a secret bank account to hide payments. But NIH's handling of the allegations raises serious questions about the agency's ability to police its own researchers.

At a hearing last week, Representative John Dingell (Democrat, Michigan), the firebrand chairman of the Energy and Commerce Committee's oversight and investigations subcommittee, asked NIH acting director William Raub, Gallo and two other NIH officials to explain their actions in the case.

Dingell noted that possible conflict of interest in Sarin's activities had first been brought to NIH's attention in April last year at a hearing on misuse of funds by Zaki Salahuddin, another researcher in Gallo's lab (see Nature 345, 99; 1990). Salahuddin later pleaded guilty and was sentenced in district court (see Nature 348, 8; 1990).

At the May hearing, Dingell revealed that a Food and Drug Administration (FDA) employee had written to the subcommittee to complain that Sarin had represented Responsif, a pharmaceutical company, at a 1985 FDA meeting, despite the fact that he was an NIH employee. Although Sarin, who was present at the Dingell hearing because he was Salahuddin's immediate supervisor, testified that his actions had been legal under $\mathrm{NIH}$ rules at the time, other NIH officials at the hearing were unable to confirm that and said that they would look into the matter.

What the officials actually did, an investigation by the congressional General Accounting Office (GAO) has revealed, was to ask Gallo to talk to Sarin about the matter. Sarin assured Gallo that "everything was taken care of", Gallo told the investigators. Dingell noted that this was exactly the way Salahuddin had successfully deflected suspicion when Gallo had questioned him on his own allegations of wrongdoing a year previously. "Apparently, these are magic words", Dingell wryly commented.

"It is discouraging", Dingell said, "that NIH did nothing to investigate the Sarin matter between the time of the April subcommittee hearing and December 1990", when his staff requested certain NIH documents that clearly showed irregularities in Sarin's consulting. Only then, when NIH were virtually handed evidence of wrongdo- 
ing, did officials investigate the case. NIH removed Sarin from his position earlier this year (see Nature 349,$95 ; 1991$ ) and the case is now being investigated by the agency's Inspector General and the US Attorney's office.

"It is not the business of the subcommittee to supervise the daily workings of the NIH. But if we have to do it, we will", Dingell threatened.

The most damaging evidence in the Sarin case revolves around an NIH fund - known as the Foundation for the Advanced Education in the Sciences (FAES) - that was used to support visiting scientists in Gallo's laboratory. According to the GAO investigators, Sarin set up a private bank account at a local bank with a similar name - FAES/ NERIC. These initials, however, stood for the "Family Account for the Education of the Sarin Children/Neil and Eric". Sarin instructed ASTA Pharma, a German pharmaceutical company, to make out a consulting cheque for $\$ 25,000$ to FAES (an illegal payment, GAO said), which he deposited in the private account, along with other consulting payments. Sarin's lawyer, W. Neil Eggleston, says that Sarin has violated no laws, but he declines to explain the details of the questioned bank account.

NIH did not spot the violations, Raub testified, because officials had not thoroughly examined Sarin's files and were not sure that he had been given correct advice when he sought approval for the consulting. "In hindsight, the level of trust was too high", he said. "One of the things we need to develop across NIH is a greater talent for selective suspicion."

Gallo testified that, although he had been asked to question Sarin about the allegations, he could do little more than accept Sarin's denial.

"If the subcommittee and the NIH know about the allegations of misconduct, I don't know what I'm doing investigating it", Gallo argued. "I'm a scientist, not a policeman."

It is not clear exactly what NIH have done to prevent and investigate conflict of interest abuses in the future. "Do you still go by the same seat-of-the-pants review process that brought about this sorry situation?", Dingell asked Richard Adamson, Gallo's superior at the National Cancer Institute (NCI).

"No", Adamson responded. He was, however, unable to specify any significant new protection in the NIH procedures prompted by the Sarin case. Raub testified that, since the Salahuddin hearing, NIH have improved its review of applications for outside consulting and started an $\mathrm{NIH}$-wide inventory of equipment. But most effort seems to have been spent in ensuring that existing procedures are being followed. $\mathrm{NCI}$ employees have been given seminars on existing conflict-of-interest rules, and outside companies will be sent copies of the relevant regulations, so that they can watch for violations as well, Raub said.

Christopher Anderson

\section{Commission bids for power}

\section{London}

As the European Communities (EC) member states debate plans for greater economic and political unity, the European Commission has launched a bold plan to wrest control over the EC's research programme from the Council of Ministers - the periodic meetings of member states' research ministers.

The move would decrease the influence that individual member states have on the precise direction of EC research. This alarms many of the member states' permanent representatives in Brussels, who are embroiled in a dispute with the Commission's controversial vice-president in charge of research, Filippo Pandolfi, over the EC's future support for basic science.

The Commission, the civil service of the $\mathrm{EC}$, is responsible for drawing up the EC's Framework research programmes, in consultation with the member states. But the goahead for individual component programmes within each Framework currently depends on the research ministers giving their approval.

The Commission's bid for increased power is put forward as a proposal to the Intergovernmental Conference that is considering plans for greater European unity. The Commission argues that each Framework should be approved in a single step, rather than individual component programmes being subject to scrutiny by the Council of Ministers after the overall budget is agreed. Under the plan, the Commission would then be able to implement the individual programme itself. This would give the Commission a large degree of control over a huge sum of money: a budget of 5,700 million ECU (about $£ 4,000$ million) was set last year for the EC's third Framework programme.

The proposal was considered by a meeting of member states' permanent representatives in Brussels late last month. Most are said to have been unenthusiastic. But the Commission has one, superficially appealing, argument to support its plan to streamline the decision-making process: the third Framework programme has become hopelessly bogged down in discussions between the Commission, the European Parliament and the member states. After almost a year, no individual programmes have yet received the research ministers' final approval.

But Pandolfi's critics say that the Commission is to blame for the delay. The problem, they argue, stems from Pandolfi's decision to present the outlines of 13 component programmes within the third Framework at one go. Previously, the European Parliament, the member states' research ministers and their permanent representatives in Brussels were able to consider programmes in smaller, more manageable batches.

To compound the administrative night- mare, the Commission was last year forced to rewrite the 13 programme outlines, because they contained too little detail. Even now, the "human capital and mobility" programme, which will take over EC support for basic scientific research, is the subject of a bitter row between Pandolfi and the member states' representatives. Pandolfi wishes to spend most of the 518 million ECU (about $£ 350$ million) on a large postdoctoral fellowship scheme, which his opponents argue vastly exceeds the demand (see Nature 349, 556; 14 February 1991).

In the light of the current chaos, Sir Peter Swinnerton-Dyer, chairman of CODEST, the committee that oversees EC support for basic research, says he cannot see the member states' research ministers agreeing to the Commission's proposal. The European Parliament is also likely to fight the plan. The parliament can influence EC research programmes through its decisions on the EC's annual budget, and is wary of any extension of the Commission's role. With this opposition, the Commission's plan is unlikely to be accepted in its present form. Nevertheless, with the EC's constitution effectively 'up for grabs' as the member states debate greater European unity, it is possible that the Commission may win some concessions and consolidate its role in directing EC research.

Peter Aldhous

\section{UK UNIVERSITIES \\ New CVCP chairman}

\section{London}

UK university vice-chancellors have chosen David Harrison from the University of Exeter to head the Committee of Vice-Chancellors and Principals (CVCP) from 1 August. Harrison, a chemist, is the second vice-chancellor to be appointed to the post in recent months. The first, Graeme Davies from the University of

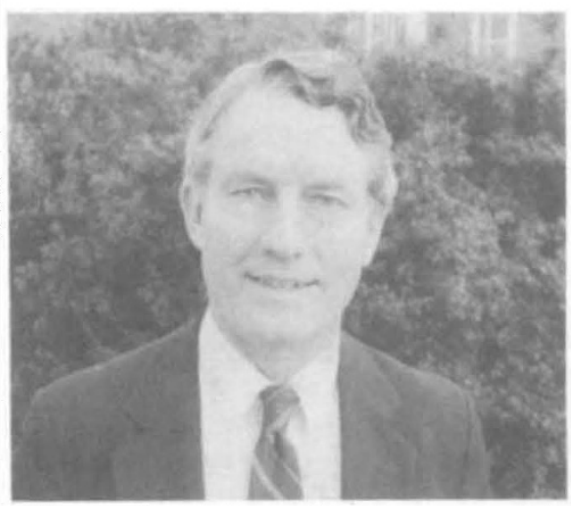

Liverpool, withdrew when he accepted the position of chief executive of the Universities Funding Council (UFC) (see Nature 349, 443; 7 February 1991). The two men face a difficult task improving strained relations between their respective bodies. PeterAldhous 